JURNAL MANAJEMEN KOMPETEN

Vol. 3 No. 2 Desember 2020, 70-84

\title{
PENGARUH DISIPLIN KERJA TERHADAP PRODUKTIVITAS KINERJA PADA KANTOR CAMAT KECAMATAN SUNGAI LILIN KABUPATEN MUSI BANYUASIN
}

\author{
Yeni Marsih ${ }^{1)}$ Utas Swarga ${ }^{2)}$ \\ marsihyeni@gmail.com ${ }^{1)}$ \\ STIE Rahmaniyah Sekayu
}

\begin{abstract}
Abstrak. Tujuan dari penelitian ini untuk mengetahui pengaruh disiplin kerja terhadap produktivitas kinerja pada kantor camat Kecamatan Sungai Lilin. Metode yang digunakan dalam penelitian ini adalah metode deskriptif kuantitatif dengan penyebaran kuisioner dan studi kepustakaan. Kemudian Analisis data dilakukan menggunakan uji validitas, uji reliabilitas, uji asumsi klasik, uji regresi sederhana, uji hipotesis. Metode yang digunakan dalam penelitian ini adalah metode deskriptif kuantitatif dengan pnyeberan kuisioner, survey dan studi kepustakaan. Kemudian Analisis data dilakukan menggunakan uji validitas, uji reliabilitas, uji regresi sederhana, uji hipotesis. Diperoleh persamaan regresi sederhana yaitu $Y=5,361+0,880 X$. Dimana nilai konstanta sebesar 5,361 menunjukkan bahwa jika disiplin kerja terhadap variabel dependen dianggap tidak ada (nol) maka produktivitas kinerja sebesar 5,361. Koefisien regresi variabel disiplin kerja $(X)$ menunjukkan pengaruh positif sebesar 0,880 terhadap produktivitas kinerja $(Y)$. Koefisien bernilai positif menunjukkan pengaruh yang searah, artinya tinggi nilai variabel disiplin kerja menyebabkan semakin tinggi produktivitas kinerja.
\end{abstract}

Keywords : Disiplin Kerja dan Produktivitas Kinerja

\section{Pendahuluan}

Instansi Pemerintah adalah organisasi yang merupakan kumpulan orang- orang yang dipilih secara khusus untuk melaksanakan tugas Negara sebagai bentuk pelayanan kepada orang banyak. Tujuan instansi pemerintah dapat dicapai apabila mampu mengolah, menggerakkan dan menggunakan sumber daya manusia yang dimiliki secara efektif dan efisien. Peran manusia dalam organisasi sebagai pegawai memegang peranan yang menentukan karena hidup matinya suatu organisasi pemerintah semata-mata tergantung pada manusia. Pegawai merupakan faktor penting penentu dalam pencapaian tujuan instansi pemerintah secara efektif dan efisien. Pegawai yang menjadi penggerak dan penentu jalannya organisasi. Faktor sumber daya manusia ini merupakan elemen yang harus diperhatikan oleh setiap instansi, terutama bila mengingat bahwa instansi pemerintah yang berhubungan dengan pelayanan publik.

Hal ini memaksa setiap instansi harus dapat bekerja dengan lebih efektif, efisien dan produktif. Dalam memberikan pelayanan publik tentunya ini akan memacu instansi pemerintah untuk dapat mempertahankan kelangsungan hidupnya. Hal ini instansi pemerintah harus memperhatikan pada aspek sumber daya manusia. Jadi manusia dapat dipandang sebagai faktor penentu, karena di tangan manusialah segala inovasi akan direalisasi dalam upaya mewujudkan tujuan instansi pemerintah.

Dalam melakukan kegiatan, pegawai memerlukan petunjuk kerja dari instansi agar 
pelaksanaanya sesuai dengan perencanaan dan harus didukung dengan peraturan kerja instansi sehingga menciptakan disiplin kerja. Pelaksanaan disiplin kerja itu sendiri harus dikelola dengan baik oleh para pegawainya karena dengan kurangnya kedisiplinan mengakibatkan produktivitas instansi menjadi turun. Dalam hal ini ada instansi harus memeprhatikan produktivitas pegawai karena merupakan salah satu kunci keberhasilan. Apabila suatu instansi melakukan aktivitas instansi pemerintah dengan produktivitas yang kurang baik maka citra instansi akan kurang baik.

Menurut Sutrisno (2003: 89). disiplin kerja pegawai adalah perilaku seseorang dengan peraturan,prosedur kerja yang ada atau disiplin adalah tingkah laku dan perbuatan yang sesuai dengan peraturan dari organisasi atau suatu pemerintahan baik secara tertulis atau tidak tertulis.

Untuk mendisiplinkan tenaga kerja dapat digunakan cara pengukuran positif (positive reinpociment) dan pengukuran negative (negative reinforcement) dan hukum ancaman, hukuman yang dipersiapkan mungkin benar-benar akan dilaksanakan jika pegawai melanggar disiplin. Disamping itu masih banyak pegawai Kecamatan yang bekerja sebagai formalitas untuk mendapatkan gaji sehingga kebanyakan pegawai lebih mengutamakan kepentingan pribadi daripada kepentingan organisasi, dan ada sebagian pegawai yang sering datang terlambat dan bolos kerja, tapi mereka baru rajin kerja apabila sudah mendekati mendapatkan gaji.

Dari hasil pengamatan sementara yang dilakukan penulis pada kantor Kecamatan Sungai Lilin Kabupaten Musi Banyuasin, maka diperoleh informasi bahwa masih adanya pegawai yang bekerja tanpa persiapan yang baik, sehingga banyak pegawai yang menunda-nunda pekerjaan dan tidak terselesaikan dengan tepat waktu, kuantitas kerja yang dihasilkan tidak mencapai target, serta kualitas kerja pegawai yang masih rendah. Hal tersebut terjadi karena masih banyak tindakan indisipliner seperti Pegawai yang datang terlambat, pegawai yang bolos kerja, banyak pegawai yang berbincang( ngobrol) pada jam kerja tanpa meminta izin terlebih dahulu. Pegawai yang bermalas malasan dalam bekerja, Pegawai yang pulang lebih cepat dari jam kerja yang telah ditetapkan, serta pegawai yang tidak mematuhi nilai-nilai atau norma yang ada.

Hal ini dapat dilihat dari kurangnya disiplin pegawai dalam menerapkan tata kerja dan prosedur kerja. Pada Kantor Camat Sungai Lilin masih terdapat pegawai yang datang ketempat kerja terlambat yang semestinya pukul 07.15 tetapi datangnya 09.00 , belum waktunya pulang sudah pulang yang semestinya pulang jam 16.00 tetapi pulang 15.00 .

Untuk lebih jelasnya bisa dilihat pada tabel 1 dibawah ini. pada bulan Febuari terdapat 2 orang tenaga honorer izin dengan persentase $9,09 \square$, kemudian dibulan maret 1 orang tenaga honorer yang

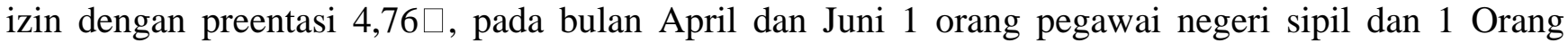
tenaga honorer izin dengan preentasi 9,52 $\square$, dan terakhir dibulan September dan Oktober terdapat 3 orang tenaga honorer izin dengan presentasi 13,63 $\square$.

Daftar Hadir Pegawai PNS Dan Honorer

\begin{tabular}{|c|c|c|c|c|c|c|c|c|c|}
\hline \multirow[t]{2}{*}{ BULAN } & \multirow[t]{2}{*}{$\begin{array}{c}\text { JUMLAH } \\
\text { HARI KERJA }\end{array}$} & \multicolumn{3}{|c|}{$\begin{array}{c}\text { PNS } \\
\text { 18 ORANG }\end{array}$} & \multicolumn{3}{|c|}{$\begin{array}{l}\text { HONORER } \\
\text { 20 ORANG }\end{array}$} & \multicolumn{2}{|c|}{ PERSENTASI } \\
\hline & & I & $\mathbf{S}$ & $\mathbf{A}$ & I & $\mathbf{S}$ & $\mathbf{A}$ & PNS & HONORER \\
\hline JANUARI & 22 Hari & - & - & - & - & - & - & $81,81 \%$ & $90,90 \%$ \\
\hline FEBUARI & 19 Hari & - & - & 1 & $\square$ & $\square$ & - & $94,73 \%$ & $94,73 \%$ \\
\hline
\end{tabular}


JURNAL MANAJEMEN KOMPETEN

Vol. 3 No. 2 Desember 2020, 70-84

\begin{tabular}{|c|c|l|l|l|l|l|l|l|l|}
\hline MARET & 21 Hari & - & - & - & $\square$ & - & - & $85,71 \%$ & $90,47 \%$ \\
\hline APRIL & 21 Hari & $\square$ & - & - & $\square$ & - & - & $80,95 \%$ & $90,47 \%$ \\
\hline MEI & 20 Hari & - & - & - & - & - & - & $90,00 \%$ & $100,00 \%$ \\
\hline JUNI & 19 Hari & $\square$ & - & - & - & $\square$ & - & $94,73 \%$ & $94,73 \%$ \\
\hline JULI & 22 Hari & - & - & - & - & - & - & $81,81 \%$ & $86,36 \%$ \\
\hline AGUSTUS & 21 Hari & - & - & - & - & - & - & $85,71 \%$ & $95,23 \%$ \\
\hline SEPTEMBER & 19 Hari & - & - & - & $\square$ & $\square$ & - & $94,73 \%$ & $94,73 \%$ \\
\hline OKTOBER & 22 Hari & - & - & - & - & $\square$ & - & $81,81 \%$ & $86,36 \%$ \\
\hline NOVEMBER & 21 Hari & - & - & - & - & - & - & $85,71 \%$ & $95,23 \%$ \\
\hline
\end{tabular}

Kantor Camat Kecamatan Sungai Lilin Kabupaten Musi Banyuasin bertugas memelihara, mengatur ,dan melayani masyarakat sungai lilin yang ada di Kabupaten Musi Banyuasin guna membantu mencapainya tujuan dari Pemerintah Kabupaten Musi Banyuasin . karena produktivitas kerja pegawai sangatlah penting maka hal-hal yang berhubungan dengan produktivitas kerja harus ditingkatkan. Pada penelitian ini peneliti ingin mengetahui apakah kedisiplinan pegawai mempunyai pengaruh terhadap produktivitas tersebut.

Berdasarkan latar belakang yang telah diuraikan di atas, maka peneliti tertarik untuk melakukan penelitian mengenai "Pengaruh Disiplin Kerja Terhadap Produktivitas Kinerja Pegawai di Kantor Camat Kecamatan Sungai Lilin Kabupaten Musi Banyuasin "

\section{Tinjauan Pustaka}

\subsection{Pengertian Disiplin Kerja}

Secara etimologis disiplin berasal dari bahasa inggris "disciple" yang berarti pengikut atau penganut pengajaran. Latihan dan sebagainya. Dispilin merupakan suatu keadaan tertentu dimana orang-orang yang tergabung dalam organisasi tunduk pada peraturan-peraturan yang ada dengan rasa senang hati. Sedangkan kerja adalah segala aktivitas manusia yang dilakukan untuk menggapai tujuan yang telah ditetapkannya. Menurut Hasibuan (2012:193) berpendapat bahwa: "Kedisiplinan adalah kesadaran dan kesediaan seseorang menaati semua peraturan perusahaan dan norma-norma sosial yang berlaku. Kedisiplinan harus ditegakkan dalam suatu organisasi perusahaan. Tanpa dukungan disiplin karyawan yang baik, sulit bagi perusahaan untuk mewujudkan tujuannya. Jadi, kedisiplinan adalah kunci keberhasilan suatu perusahaan dalam mencapai tujuannya.”

Zainal (2014; 599) disiplin kerja adalaha suatu alat yang digunakan para manajer untuk berkomunikasi dengan karyawan agar mereka bersedia mengubah suatu prilaku serta sebagai suatu upaya untuk meningkatkan kesdaran dan kesedian seorang menanti semua peraturan perusahaan dan norma norma sosial yang berlaku.

Hasibuan (2013: 194) disiplin adalah kesadaran dan kesedian seorang menaati semua peraturan peraturan perusahaan atau organisasi dan norma yang berlaku. 
JURNAL MANAJEMEN KOMPETEN

Vol. 3 No. 2 Desember 2020, 70-84

Darmawan (2013: 41) menyatakan disiplin kerja diartikan sebagai suatu sikap,tingkah laku, dan perbuatan yang sesuai peraturan dari organisasi dalam bentuk tertulis maupun tidak

\subsection{Bentuk-Bentuk Kedisiplinan}

Menurut zainal (2014: 599) bentuk bentuk disiplin kerja terdiri dari:

1) Disiplin retributif yaitu berusaha menghukum orang yang berbuat salah

2) Disiplin korektif yaitu berusaha membantu karyawan mengoreksi perilakunya yang tidak tepat

3) Perspektif hak hak individu yaitu berusaha melindungi hak hak dasar individu selama tindakan tindakan disipliner

4) Perspektif utilitarian yaitu berfokus pada penggunaan disiplin hanya pada saat konsekuensi konsekuensi tindakan displin melebihi dampak dampak negatif

\subsection{Indikator-Indikator Kedisiplinan}

Pada dasarnya banyak indikator yang mempengaruhi kedisisplinan pegawai namun dalam hal ini penulis menggunakan indikator didisiplin kerja Menurut Zaianal (2014: 599), yaitu:

1) Konsekuen

Apabila seorang pegawai melakukan suatu kesalahan, maka pegawai tersebut harus

konsekuen terhadap aturan pelanggaran. Artinya soerang pegawai harys siap terhadap sanksi atau kebijakan yang berlaku. Apabila tidak dilakukan secara konsekuen berarti pegawai tersebut melecehkan peraturan yang telah ditetapkan

2) Konsisten

Setiap pegawai dan penyelia perlu memahami kebijakan serta mengikuti prosedur secara penuh. Dalam konteks disiplin keadilan harus dirawat dengan konsisten tanpa pilih kasih jika seorang sedang menghadapi tantangan disipliner, maka penyelia harus dapat membuktikan bahwa yang terlibat kelakuan yang patut tidak dihukum. Setiap pegawai yang bersalah harus dibina, sehingga mereka mereka tidak merasa dihukum dan dapat menerima sanksi yang dilakukan dengan wajar

3) Taat Asas

Penegakan disiplin membutuhkan kesadaran dan kesedian seseorang untuk menaati semua peraturan dan norma-norma sosial yang berlaku dalam organisasi. Jika semua unsur yang berkompeten terhadap asas, maka bukan suatu yang sukar segala komponen kegiatan dan aktivitas ini dapat berjalan dengan tertib

4) Bertanggung Jawab Disiplin yang baik mencerminkan besarnya tanggung jawab seorang pegawai terhadap tugastugas yang diberikan kepadanya hal ini mendorong semangat kerja dan terwujudnya tujuan organisasi, pegawai, dan masyarakat umumnya.

\subsection{Faktor-faktor yang Mempengaruhi Kedisiplinan}

Banyak faktor yang dapat mempengaruhi tegak tidaknya suatu disiplin kerja dalam suatu Instansi Pemerintah. Menurut Saydam (2000:202), faktor-faktor tersebut antara lain:

1. Besar kecilnya pemberian kompensasi

2. Ada tidaknya keteladanan pimpinan dalam perusahaan

3. Ada tidaknya aturan pasti yang dapat dijadikan pegangan

4. Keberanian pimpinan dalam mengambil tindakan

5. Ada tidaknya pengawasan pimpinan 
JURNAL MANAJEMEN KOMPETEN

Vol. 3 No. 2 Desember 2020, 70-84

6. Ada tidaknya perhatian kepada pegawai

7. Diciptakan kebiasaan-kebiasaan yang mendukung tegaknya disiplin.

\subsection{Pengertian Produktivitas Kerja}

Produktivitas berasal dari kata "produktif" artinya sesuatu yang mengandung potensi yang digali, sehingga produktivitas dapatlah dikatakan suatu proses kegiatan yang terstruktur guna menggali potensi yang ada dalam sebuah komoditi atau objek. Filosofi produktivitas sebenarnya dapat mengandung arti keinginan dan usaha dari setiap manusia maupun kelompok untuk selalu meningkatkan mutu kehidupan dan penghidupannya.

Setiap organisasi selalu berusaha agar para pegawai dapat berprestasi dalam bentuk memberikan produktivitas kerja yang maksimal. Produktivitas pegawai dalam organisasi sangat penting sebagai alat pengukur keberhasilan dalam menjalankan roda pemerintahan. Sebab semakin tinggi produktivitas kerja pegawai dalam organisasi, maka akan semakin baik kualitas dan kuantitas pekerjaan yang dihasilkan dalam suatu perusahaan.

Menurut Hasibuan (2011: 110) produktivitas adalah perbandingan antara output (hasil) dengan input (pemasukan) dimana output harus mempunyai nilai tambahan atau Teknik pengerjaan yang lebih baik.

Sedangkan Sinungan (2010: 17) mengemukakan bahwa produktivitas kerja adalah suatu konsep yang bersifat universal yang bertujuan untuk menyediakan lebih banyak barang dan jasa untuk lebih banyak manusia, dengan menggunakan sumber rill yang semakin sedikit.

Bedasarkan pendapat para ahli diatas maka dapat disimpulkan bahwa produktivitas adalah kemampuan memaksimalkan sumber daya yang digunakan yntyk meningkatkan kualitas dan kuantitas pekerjaan yang dihasilkan dlam suatu organisasi atau perusahaan.

\subsection{Faktor-Faktor yang Mempengaruhi Produktivitas Kerja}

Dalam upaya meningkatkan produktivitas kerja pegawai dilembaga pemerintahan perlu diperhatikan faktor-faktor yang mempengaruhi produktivitas kerja pegawai tersebut. Faktor-faktor yang berhubungan dengan lingkungan kerja serta kebijakan pemerintahan secara keseluruhan.

Menurut Sulistyani dan Rosdiah yang dikutip oleh Hartati (2014: 213), ada beberapa faktor yang mempengaruhi produktivitas pegawai, antara lain:

1. Knowledge

Pengetahuan merupakan akumulasi hasil proses pendidikan baik yang diperoleh secara formal maupun non formal yang memberikan kontribusi pada seseorang di dalam pemecahan masalah, daya cipta, termasuk dalam melakukan atau menyelesaikan pekerjaan. Dengan pengetahuan yang luas dan pendidikan yang tinggi, seorang pegawai diharapkan mampu melakukan pekerjaan dengan baik dan produktif.

2. Skills

Ketrampilan adalah kemampuan dan penguasaan teknis operasional mengenai bidang tertentu, yang bersifat kekaryaan. Ketrampilan diperoleh melalui proses belajar dan berlatih.

Ketrampilan berkaitan dengan kemampuan seseorang untuk melakukan atau menyelesaikan pekerjaan- pekerjaan yang bersifat teknis. Dengan ketrampilan yang dimiliki seorang pegawai diharapkan mampu menyelesaikan pekerjaan secara produktif.

3. Abilities

Abilities atau kemampuan terbentuk dari sejumlah kompetensi yang dimilki oleh seorang pegawai. Konsep ini jauh lebih luas, karena dapat mencakup sejumlah kompetensi. Pengetahuan 
dan ketrampilan termasuk faktor pembentuk kemampuan. Dengan demikian apabila seseorang mempunyai pengetahuan dan ketrampilan yang tinggi, diharapkan memilki ability yang tinggi pula.

4. Attitude

Attitude merupakan suatu kebiasaan yang terpolakan. Jika kebiasaan yang terpolakkan tersebut memilki implikasi positif dalam hubungannya dengan perilaku kerja seseorang maka akan menguntungkan. Artinya apabila kebiasaan-kebiasaan pegawai adalah baik, maka hal tersebut dapat menjamin perilaku kerja yang baik pula. Dapat dicontohkan seorang pegawai mempunyai kebiasaan tepat waktu, disiplin, simple, maka perilaku kerja juga baik, apabila diberi tanggung jawab akan menepati aturan dan kesepakatan.

5. Behaviors

Demikian dengan perilaku manusia juga akan ditentukan oleh kebiasaan kebiasaan yang telah tertanam dalam diri pegawai sehingga dapat mendukung kerja yang efektif atau sebaliknya. Dengan kondisi pegawai tersebut, maka produktivitas dapat dipastikan akan dapat terwujud. (Ambar Teguh \& Rosidah, 2003).

\subsection{Indikator Produktivitas Kerja}

Menurut Hasibuan (2011: 110) faktor-faktor yang digunakan dalam mengukur produktivitas kerja yaitu kualitas kerja,kuantitas kerja, dan ketepatan waktu. Dalam penelitian ini penulis mengukur produktivitas kerja dengan menggunakan indikator-indikator dibawah ini :

1. Kualitas Kerja

Kualitas kerja adalah suatu standar hasil yang berkaitan dengan mutu dari suatu produkyang dihasilkan oleh pegawai, dalam hal ini merupakan kemampuan karyawan dalam menyelesaikan pekerjaan teknis dengan perbandingan standar yang ditetapkan

2. Kuantitas Kerja

Kuantitas kerja adalah suatu hasil yang dicapai oleh pegawai dengan jumlah tertentu dengan perbandingan standar yang ada

3. Ketepatan Waktu

Merupakan tingkatan suatu aktivasi diselesaikan dengan waktu yang ditentukan, dilihat dari sudut koordinasi dengan hasil output serta memaksimalkan waktu yang tersedia untuk aktivasi lain.ketepatan waktu diukur dari persepsi pegawai terhadap suatu aktivasi yang disediakan awal waktu sampai menjadi output.

\subsection{Kerangka Pemikiran}

Sebagai acuan dalam penyusunan proposal ini, maka penulis menyusun kerangka pemikiran yaitu sebagai berikut. Adapun kerangka berfikir antara variabel bebas dan variabel terikat secara skematis dalam gambar 


\begin{tabular}{||l||l||}
\hline \multicolumn{1}{|l|}{ Disiplin Kerja (X) } \\
1. Konsekuen \\
2. Konsisten \\
3. Taat asas \\
4. Tanggung jawab \\
Sumber : Zainal (2014: 560)
\end{tabular}

\section{Gambar 2.1 Kerangka Pemikiran}

Pada kerangka pemikiran diatas memaparkan dengan adanya disiplin kerja setiap pegawai dapat melaksanakan tugasnya secara efektif dan efisien. Disiplin menjadi prasyarat bagi pembentuk sikap,prilaku, dan tata kehidupan pegawai sehingga menghasilkan kemudahan dalam pekerjaan serta mendukung usaha pencapaian tujuan.

Disiplin dalam bekerja sangatlah penting, seperti melatih kepribadian. Disiplin yang tinggi mencerminkan besarnya tanggung jawab seorang terhadap tugas tugas yang diberikan kepadanya. Sebab hal ini akan mendorong gairah dan semangat kerja dan mendorong tercapainya produktivitas kerja yang baik.

\subsection{Hipotesis}

Berdasarkan kerangka pemikiran diatas dapat diajukan hipoteseis penelitian adalah belum terlaksananya dengan baik antara Pengaruh Disiplin Kerja Terhadap Produktivitas Kinerja Pegawai Di Kantor Camat Sungai Lilin Kabupaten Musi Banyuasin dilihat dari indikator disiplin kerja seperti melaksanakan tugas sesuai tugas pokok, saling menghormati dan menghargai sesama pegawai, patuh aturan, dan hubungan kemanusiaan.

\section{Metodologi Penelitian}

\subsection{Data}

Penelitian ini menggunakan Metode Kuantitatif . Menurut Sugiyono (2014: 7 ) Metode Kuantitatif dinamakan metode tradisional karena metode ini sudah cukup lama digunakan sehingga sudah mentradisi sebagai metode untuk penelitian. Sumber data primer ini berupa catatan hasil wawancara yang diperoleh melalui wawancara yang penulis lakukan. Selain itu penulis juga melakukan observasi lapangan dan mengumpulkan data dalam bentuk catatan tentang situasi dan kejadian di perpustakaan, dalam hal ini data yang dimaksud adalah Kantor Camat Sungai Lilin. Sumber data sekunder ini digunakan untuk mendukung informasi dari data primer yang diperoleh baik dari wawancara, maupun dari observasi langsung ke lapangan. Penulis juga menggunakan data sekunder hasil dari studi pustaka. 
JURNAL MANAJEMEN KOMPETEN

Vol. 3 No. 2 Desember 2020, 70-84

\subsection{Operasionalisasi Variabel}

Tabel 2.1 Operasionalisasi Variabel

\begin{tabular}{|c|c|c|c|c|}
\hline Variabel & DefinisiVariabel & Indikator & $\begin{array}{c}\text { Item } \\
\text { Pernyataan }\end{array}$ & Skala \\
\hline $\begin{array}{l}\text { Disiplin } \\
\text { Kerja (X) }\end{array}$ & $\begin{array}{l}\text { Zainal (2014; 599) disiplin kerja } \\
\text { adalaha suatu alat yang digunakan } \\
\text { para manajer untuk berkomunikasi } \\
\text { dengan karyawan agar mereka } \\
\text { bersedia mengubah suatu prilaku serta } \\
\text { sebagai suatu upaya untuk } \\
\text { meningkatkan kesdaran dan kesedian } \\
\text { seorang menanti semua peraturan } \\
\text { perusahaan dan norma norma sosial } \\
\text { yang berlaku. }\end{array}$ & $\begin{array}{l}\text { Konsekuensi } \\
\text { Konsisten } \\
\text { Taat Asas } \\
\text { Tanggung } \\
\text { Jawab }\end{array}$ & $\begin{array}{c}1-2 \\
3-4 \\
5-7 \\
8-10\end{array}$ & Ordinal \\
\hline $\begin{array}{l}\text { Produktivi } \\
\text { tas kerja } \\
\text { (Y) }\end{array}$ & $\begin{array}{l}\text { Hasibuan }(2011: 110) \text { Produktivitas } \\
\text { kerja adalah perbandingan antara } \\
\text { output dengan input dimana output } \\
\text { harus mempunyai nilai tambah atau } \\
\text { Teknik pengerjaan yang lebih baik. }\end{array}$ & $\begin{array}{l}\text { Kualitas } \\
\text { Kuantitas } \\
\text { Ketepatan } \\
\text { Waktu }\end{array}$ & $\begin{array}{c}1-3 \\
4-6 \\
7-10\end{array}$ & Ordinal \\
\hline
\end{tabular}

\subsection{Populasi, Sampel dan Teknik Sampling}

Menurut Sugiyono (2009:49) Populasi merupakan "wilayah generalisasi yang terdiri atas objek/subjek yang memiliki kualitas dan karakteristik tertentu yang ditetapkan oleh peneliti untuk dipelajari dan kemudian ditarik kesimpulannya". Jadi populasi bukan hanya orang, tetapi juga objek dan benda alam yang lain. Populasi juga bukan sekedar jumlah yang ada pada subjek/objek yang dipelajari, tetapi meliputi seluruh karakteristik/sifat yang dimiliki oleh subjek atau objek yang diteliti. Kuesioner ini disebarkan kepada 42 responden yang mana respondennya adalah pegawai Kecamatan Sungai Lilin Kabupaten Musi Banyuasin .

Menurut Suharsimi Arikunto (2007: 117) sampel adalah sebagian wakil dari populasi yang diteliti, sampel dalam penelitian ini diambil dengan menggunakan rumus slovin menurut Sanusi: sampel adalah seleksi dari bagian elemen elemen populasi, hasil seleksi dapat dapat merefleksikan seluruh karakteristik yang ada sampel pada penelitian menggunakan rumus Slovin sebagai berikut:

$n=\frac{\mathrm{N}}{1+N(e)^{2}}$

\section{$=38$ Responden}

\subsection{Teknik Pengolahan Data}

Untuk mengetahui uji statistik antara variabel $\mathrm{X}$ dan variabel $\mathrm{Y}$ digunakan analisis korelasi dengan menggunakan perangkat lunak dengan menggunakan perangkat lunak program SPSS. Dalam penelitian ini penulis menggunakan skala likert. Skala likert merupakan skala pengukuran yang mengatur sikap dan pendapat seseorang atau sekelompok orang tentang fenomena sosial. Fenomena sosial tersebut merupakan suatu variabel penelitian yang akan diukur. Sebelum diukur, variabel 
tersebut dijabarkan menjadi indikator variabel yang kemudian indikator variabel tersebut digunakan sebagai tolak ukur menyusun item-item instrument yang berupa pertanyaan dan pernyataan.

\subsection{Pengujian Validitas Data}

Untuk pengujian validitas tiap butir digunakan analisis item, yaitu mengkorelasikan skor tiap butir dengan skor total yang merupakan jumlah tiap skor butir. Dengan menggunakan fasilitas SPSS, dicari nilai korelasi masing-masing item. Butir pertanyaan dinyatakan valid jika corrected Item - Total Correlation item pertanyaan lebih besar dari r Product Moment Table dengan taraf signifikan sebesar $5 \%$.

\subsection{Uji Reliabilitas}

Uji reliabilitas adalah alat untuk mengukur suatu kuesioner yang mempunyai indikator dari variable atau kontruk. Suatu kuesioner dinyatakan realibel atau handal jika jawaban terhadap pernyataan adalah konsisten atau stabil dari waktu ke waktu.

Suatu konstruk atau variable dikatakan reliabel jika memberikan nilai crobanch alpa >0,60.

\subsection{Analisis Regresi Sederhana.}

Analisis regresi sederhana merupakan analisis yang dilakukan untuk mengetahui hubungan antara dua variabel adapun rumus umum dari regresi linier sederhana sebagai berikut:

$$
\mathrm{Y}=\mathrm{a}+\mathrm{bX}
$$

\subsection{Analisis Korelasi}

Menurut Sanusi (2013: 122) fungsi utama dan analisis korelasi adalah untuk menentukan seberapa erat hubungan antara satu variabel dengan variabel lainnya sebagaimana dijelaskan analisis korelasi yaitu analisis untuk melihat sejauh mana keterkaitan antara variabel (X) Disiplin dengan variabel terkait (Y) yaitu Produktivitas Kerja Pegawai dengan mengguankan rumus korelasi yang digunakan adalah sebagai berikut:

$$
\begin{array}{r}
r_{x y}=\frac{N \sum X Y-\sum X \sum Y}{\sqrt{N \sum X^{2}-\left(\sum X\right)^{2}} \cdot \sqrt{N \sum Y-\left(\sum Y\right)^{2}}} \\
\text { www.konsistensi.com }
\end{array}
$$

\subsection{Uji Hipotesis}

Menurut Sugiyono (2016: 215), Uji t digunakan untuk menguji hipotesis secara parsial guna menunjukkan pengaruh tiap variabel independen secara induvidu terhadap variabel dependen. Uji $t$ adalah pengujian koefisien regresi masing-masing variabel independent terhadap variabel dependent untuk mengetahui seberapa besar pengaruh variabel independent terhadap variabel dependent.

Ho : Diduga tidak ada pengaruh signifikan antara disiplin kerja terhadap Produktivitas Kinerja Pegawai pada Kantor Camat Kecamatan Sungai Lilin Kabupaten Musi Banyuasin

Ha : Diduga ada pengaruh signifikan antara disiplin kerja terhadap Produktivitas Kinerja Pegawai pada Kantor Camat Kecamatan Sungai Lilin Kabupaten Musi Banyuasin 
Adapun kriteria penilaian:

a. Jika thitung $<\mathrm{t}$ tabel atau Sig $\mathrm{t}>\operatorname{Sig} \alpha=0,05$ maka H0 diterima dan Ha ditolak

b. Jika thitung $>\mathrm{t}$ tabel atau Sig $\mathrm{t}<\operatorname{Sig} \alpha=0,05$ maka H0 ditolak dan Ha diterima

\subsection{Analisis Koefisien Determinasi (uji $\left.\mathbf{r}^{2}\right)$}

Koefesien Determinasi menurut supangat (2008: 350) yaitu Koefisien determinasi adalah besaran untuk menunjukan tingkat kekuatan hubungan antara dua variabel atau lebih dalam bentuk persen (menunjukan seberapa besar persentase keragaman " $y$ " yang dapat dijelaskan oleh keragaman "x") atau dengan kata lain seberapa besar "x" dapat memberikan kontribusi kepada " $y$ " bedasarkan pengertian diatas, maka koefisien determinasi merupakan bagian dari keberagaman total dari variabel tidak bebas yang dapat diperhitungkan oleh keragaman variabel bebas dihitung dengan koefisien diterminasi dengan asumsi dasar faktor-faktor lain diluar variabel dianggap tetap atau konstan. Untuk mengetahui nilai koefisien diterminasi maka dapat dihitung dengan menggunakan rumus:

\section{$\mathrm{KD}=\mathrm{r}^{2} \times 100 \%$}

\section{Hasil dan Pembahasan}

\subsection{Pengujian Validitas Data}

Uji vadilitas dilakukan untuk mengetahui tingkat kevalidan indikator yang digunakan sebagai alat ukur variable. Pengujian vadilitas menggunakan korelasi bivariate yang dilakukan dengan menghitung korelasi antara skor masing-masing butir pertanyaan dengan total skor variabel dengan ketentuan sing. Nilai sig ( 2 - tailed) $<0,05$ berarti valid. Berikut ini hasil uji vadilitas masing-masing indikator.

\section{Uji Validasi Disiplin Kerja}

\begin{tabular}{|c|c|c|c|}
\hline Variabel & Nilai Korelasi & r Tabel & Keterangan \\
\hline X1 & 0,784 & 0,2638 & Valid \\
\hline X2 & 0,819 & 0,2638 & Valid \\
\hline X3 & 0,845 & 0,2638 & Valid \\
\hline X4 & 0,855 & 0,2638 & Valid \\
\hline X5 & 0,932 & 0,2638 & Valid \\
\hline X6 & 0,884 & 0,2638 & Valid \\
\hline X7 & 0,912 & 0,2638 & Valid \\
\hline X8 & 0,823 & 0,2638 & Valid \\
\hline X9 & 0,838 & 0,2638 & Valid \\
\hline X10 & 0,684 & 0,2638 & Valid \\
\hline
\end{tabular}

Sumber : Data (Diolah) SPSS Versi 15,0 
Berdasarkan tabel diatas mengenai hasil validitas dapat diketahui bahwa, item pertanyaan/indikator-indikator variabel disiplin kerja yaitu nilai sig. (2-tailed) $<0,5$ ini berarti bahwa dari hasil variabel disiplin kerja dinyatakan valid karena dari hasil korelasi antara hasil jawaban responden pada tiap item pertanyaan/indikator dengan skor didapat dari hasil yang signifikasi, disiplin kerja valid

Uji Validitas Produktivitas Kinerja (Variabel Y)

\begin{tabular}{|c|c|c|c|}
\hline Variabel & Nilai Korelasi & r Tabel & Keterangan \\
\hline Y1 & 0,833 & 0,2638 & Valid \\
\hline Y2 & 0,856 & 0,2638 & Valid \\
\hline Y3 & 0,867 & 0,2638 & Valid \\
\hline Y4 & 0,790 & 0,2638 & Valid \\
\hline Y5 & 0,673 & 0,2638 & Valid \\
\hline Y6 & 0,690 & 0,2638 & Valid \\
\hline Y7 & 0,945 & 0,2638 & Valid \\
\hline Y8 & 0,767 & 0,2638 & Valid \\
\hline Y9 & 0,728 & 0,2638 & Valid \\
\hline Y10 & 0,723 & 0,2638 & Valid \\
\hline
\end{tabular}

Sumber : Data (Diolah) SPSS Versi 15,0

Berdasarkan tabel 4.8 diatas mengenai hasil validitas dapat diketahui bahwa, item pertanyaan/indikator-indikator variabel produktivitas kinerja dinyatakan valid karena dari hasil korelasi antara hasil jawaban responden pada tiap item-item yang ada pada pertanyaan/indikator dengan skor total didapat dari hasil-hasil yang signifikan, yaitu nilai sig. (2-tailed) $<0,05$ ini berarti bahwa dari hasil yang variabel produktivitas kinerja valid.

\subsection{Uji Reliabilitas}

Uji reliabilitas digunakan untuk mengetahui apakah pertanyaan/indikator yang digunakan dapat dipercaya atau handal sebagai alat ukur variabel, apabila nilai crobach's alpa suatu variabel sedangkan apabila crobach's alpa suatu variabel < 0,60 maka indikator yang digunakan oleh variabel tersebut tidak reliabel. Hasil uji reliabilitas adalah sebagai berikut :

Uji Reliabilitas

\begin{tabular}{|l|l|l|}
\hline \multicolumn{1}{|c|}{ Variabel } & \multicolumn{1}{c|}{ crobach's alpa } & \multicolumn{1}{c|}{ Keterangan } \\
\hline Disiplin Kerja (X) & 0,954 & Reliabel \\
\hline Produktivitas Kinerja (Y) & 0,929 & Reliabel \\
\hline
\end{tabular}

Sumber : Data (Diolah) SPSS Versi 15,0

Berdasarkan tabel uji reliabilitas diatas dapat diketahui bahwa, hasil uji reliabilitas memperlihatkan nilai crobach's alpa semua variabel diatas 0,60, sehingga dapat disimpulkan indikator 
yang digunakan oleh disiplin kerja dan produktivitas kinerja dapat dipercaya atau handal untuk digunakan sebagai alat ukur dari variabel.

\subsection{Analisis Regresi Sederhana}

Analisis regresi linier sederhana digunakan dalam penelitian ini dengan tujuan untuk membuktikan hipotesis mengenai pengaruh variabel disiplin kerja terhdapa produktivitas kinerja. perhitungan statistik dalam analisis regresi linier sederhana yang digunakan dalam penelitian ini adalah dengan menggunakan bantuan program komputer SPSS For Windows Relase 15,0. Hasil pengolahan data dengan menggunakan program SPPS dapat dilihat pada tabel 4.9 berikut ini :

\section{Koefisien Regresi Sederhana}

Coefficients(a)

\begin{tabular}{|c|c|c|c|c|c|}
\hline \multirow[b]{2}{*}{ Model } & \multicolumn{2}{|c|}{$\begin{array}{l}\text { Unstandardized } \\
\text { Coefficients }\end{array}$} & \multirow{2}{*}{$\begin{array}{l}\text { Standardize } \\
\mathrm{d} \\
\text { Coefficients } \\
\text { Beta }\end{array}$} & $\mathrm{T}$ & Sig. \\
\hline & B & Std. Error & & B & Std. Error \\
\hline $\begin{array}{l}\text { (Constant } \\
\text { TotalX }\end{array}$ & $\begin{array}{l}5,36 \\
1 \\
, 880\end{array}$ & $\begin{array}{l}2,00 \\
3 \\
, 050\end{array}$ & 947 & $\begin{array}{l}2,67 \\
6 \\
17,62 \\
7\end{array}$ & $\begin{array}{l}, 01 \\
1 \\
, 00 \\
0\end{array}$ \\
\hline
\end{tabular}

a Dependent Variable: TotalY

Sumber : Data (Diolah) SPSS Versi 15,0

Berdasarkan tabel diatas maka didapat persamaan regresi sederhana sebagai berikut:

$\mathrm{Y}=\mathbf{5 , 3 6 1}+\mathbf{0 , 8 8 0 X}$

Dimana :

$\mathrm{X}=$ Disiplin Kerja

$\mathrm{Y}=$ Produktivitas Kinerja

Interpetasi dari persamaan regresi sederhana mengenai pengaruh variabel indenpenden yaitu disiplin kerja terhadap variabel dependen yaitu produktivitas kinerja dapat dijelaskan sebagai berikut :

1. Nilai konstanta sebesar 5,361 menunjukkan bahwa jika disiplin kerja terhadap variabel dependen dianggap tidak ada (nol) maka produktivitas kinerja sebesar 5,361.

2. Koefisien regresi variabel disiplin kerja $(\mathrm{X})$ menunjukkan pengaruh positif sebesar 0,880 terhadap produktivitas kinerja (Y). Koefisien bernilai positif menunjukkan pengaruh yang searah, artinya tinggi nilai variabel disiplin kerja menyebabkan semakin tinggi produktivitas kinerja.

Hasil penelitian menunjukkan bahwa disiplin kerja berpengaruh terhadap produktivitas kinerja. hal ini dapat dilihat dari persamaa hasil regresi sebagai berikut:

$\mathrm{Y}=\mathbf{5 , 3 6 1 + 0 , 8 8 0 X}$

Artinya, disiplin kerja yang baik akan memberikan produktivitas kinerja, baik dari sikap dan keyakinan. Dapat dikatakan bahwa semakin tinggi pengaruh disiplin kerja, maka semakin tinggi pula produktivitas kinerja. sebaikanya semakin rendah disiplin kerja, maka semakin rendah pula produktivitas kinerja. 
JURNAL MANAJEMEN KOMPETEN

Vol. 3 No. 2 Desember 2020, 70-84

\subsection{Analisis Korelasi}

Analisis korelasi (r) digunakan untuk mengukur tinggi rendahnya derajat hubungan antar variabel yang diteliti. Tinggi rendahnya derajat keeratan tersebut dapat dilihat dari koefisien korelasinya. Hasil pengelolahan data dengan menggunakn program komputer SPSS For Windows relase 15,0 dapat dilihat pada tabel berikut ini:

\section{Koefisien Korelasi}

Model Summary

\begin{tabular}{|l|r|r|rr|r|}
\hline & & R Square & $\begin{array}{l}\text { Adjusted R } \\
\text { Square }\end{array}$ & \multicolumn{2}{l|}{$\begin{array}{l}\text { Std. Error of the } \\
\text { Estimate }\end{array}$} \\
\hline 1 & $\mathrm{R}$ &, $947(\mathrm{a}$ &, 896 &, 893 & 2,104 \\
\hline
\end{tabular}

a Predictors: (Constant), TotalX

Sumber: Data (Diolah) SPPS Versi 15.0

Berdasarkan tabel maka didapat nilai korelasi variabel disiplin kerja (r) sebesar 0,947. Dari penafsiran terhadap koefisien korelasi tersebut dapat diketahui bahwa terjadi hubungan positif yang sangat kuat antara disiplin kerja dan produktufitas kinerja. sedangkan nilai $\mathrm{R}^{2}$ ( $\mathrm{R}$ Square) sebesar 0,896 atau 89,6\% menunjukkan bahwa variabel disiplin kerja mempengaruhi oleh variabel lain produktivitas kinerja, sedangkan 10,4\% variabel lain yang tidak di teliti dalam penelitian ini.

\subsection{Uji Hipotesis}

Koefisien Regresi Sederhana

Coefficients(a)

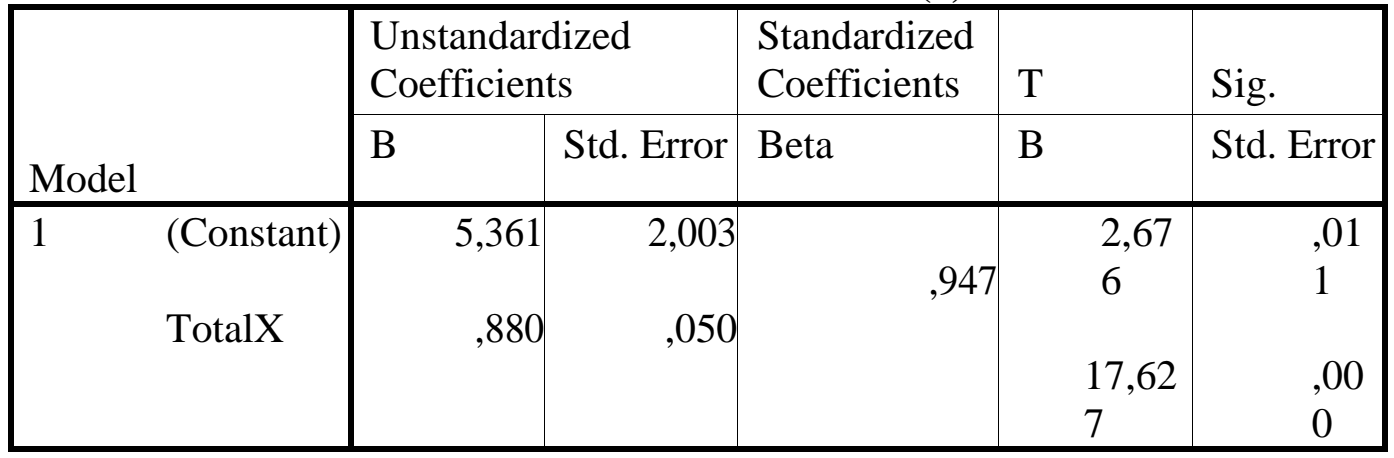

a Dependent Variable: TotalY

Sumber : Data (Diolah) SPSS Versi 15,0

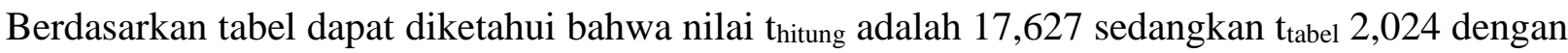
tingkat signifikasi 0,000, oleh karena nilai $t_{\text {hitung }}>t_{\text {tabel }}$ yaitu 17,627 > 2,024 dan signifikansi $0,000<$ 0,05 maka $\mathrm{H}_{\mathrm{o}}$ ditolak, artinya bahwa ada hubungan secara signifikasi antara disiplin kerja, karena $t_{\text {hitung }}$ nilainya positif, berarti bahwa disiplin kerja memiliki pengaruh positif yang signifikansi terhadap produktivitas kinerja. semakin baik disiplin kerja yang diberikan semakin tinggi pula produktivitas kinerja.

\subsection{Analisis Koefisien Determinasi $\left(\mathbf{U j i}^{\mathbf{2}} \mathbf{r}^{2}\right.$}

Koefisien determinasi merupakan besaran yang menunjukkan besarnya variasi variabel dependen yang dapat dijelaskan oleh variabel indenpendenya. Niali koefisien determinasi ditentukan dengan nilai 
adjusted $\mathrm{R}$ square sebagaimana dapat dilihat pada tabel :

Koefisien Korelasi Model Summary

\begin{tabular}{|l|l|lr|r|r|}
\hline Model & R & & R Square & $\begin{array}{l}\text { Adjusted R } \\
\text { Square }\end{array}$ & \multicolumn{2}{l|}{$\begin{array}{l}\text { Std. Error of the } \\
\text { Estimate }\end{array}$} \\
\hline 1 & &, $947(\mathrm{a}$ &, 896 &, 893 & 2,104 \\
\hline
\end{tabular}

a Predictors: (Constant), TotalX

Sumber: Data (Diolah) SPSS Versi 15,0

Hasil perhitungan regresi dapat diketahui bahwa koefisien determinasi (adjusted $R^{2}$ ) yang diperoleh sebesar 0,893 atau 89,3\% variabel Produktivitas kinerja Pegawai Kecamatan Sungai Lilin Kabupaten Musi Banyuasin dapat dijelaskan oleh variabel disiplin kerja, sedangkan sisa nya sebesar 10,7 diterangkan oleh variabel lain seperti kompensasi, lingkungan kerja, tingkat pendidikan yang tidak dianalisis dalam penelitian ini.

\subsection{Impementasi hasil Penelitian}

Berdasarkan hasil penelitian yang telah dilakukan dan berdasarkan kuesiner yang telah disebarkan didapatlah hasil bahwa koefisien regresi disiplin kerja sebesar 0,880, hal ini berarti kompensasi, tingkat pendidikan, dan lingkunagn kerja mempunyai pengaruh yang positif dan signifikan terhadap produktivitas kinerja sedangkan koefisien korelasi 0.947 menunjukan bahwa terjadi hubungan positif yang kuat antara displin kerja terhadap protivitas kinerja.

\section{Simpulan}

Berdasarkan pembahasan yang telah diuraikan pada bab sebelumnya, maka dapat ditarik simpulannya sebagai berikut:

1. Nilai korelasi variabel disiplin kerja (r) sebesar 0,947. Dari penafsiran terhadap koefisien korelasi tersebut dapat diketahui bahwa terjadi hubungan positif yang sangat kuat antara disiplin kerja dan produktivitas kinerja. sedangkan nilai $\mathrm{R}^{2}$ ( $\mathrm{R}$ Square) sebesar 0,896 atau 89,6\% menunjukkan bahwa variabel disiplin kerja dipengaruhi oleh variabel lain produktivitas kinerja, sedangkan 10,4\% dipengaruhi oleh variabel lain yang tidak di teliti dalam penelitian ini.

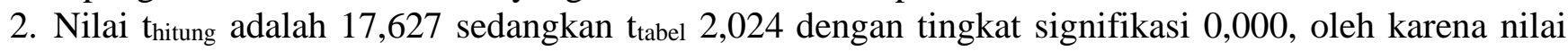
$\mathrm{t}_{\text {hitung }}>\mathrm{t}_{\text {tabel }}$ yaitu 17,627 $>2,024$ dan signifikansi 0,000 $<0,05$ maka $\mathrm{H}_{\mathrm{o}}$ ditolak, artinya bahwa ada hubungan secara signifikasi antara disiplin kerja, karena thitung nilainya positif, berarti bahwa disiplin kerja memiliki pengaruh positif yang signifikansi terhadap produktivitas kinerja. semakin baik disiplin kerja yang diberikan semakin tinggi pula produktivitas kinerja

3. Hasil perhitungan regresi dapat diketahui bahwa koefisien determinasi (adjusted $R^{2}$ ) yang diperoleh sebesar 0,893 atau 89,3\% variabel produktivitas kinerja Pegawai Kecamatan Sungai Lilin Kabupaten Musi banyuasin dapat dijelaskan oleh variabel disiplin kerja, sedangkan sisa nya sebesar 10,7 diterangkan oleh variabel lain yang tidak dianalisis dalam penelitian ini.

4. Berdasarkan hasil pengujian secara statistik dapat dilihat dengan jelas bahwa secara parsia (individu) variabel bebas berpengaruh terhadap variabel terikat. Pengaruh yang diberikan variabel bebas tersebut bersifat positif artinya semakin bagus disiplin kerja maka mengakibatkan semakin tinggi dan baik pula produktivitas kinerja. Hasil tersebut sesuai dengan hipotesis yang diajukan. 
JURNAL MANAJEMEN KOMPETEN

Vol. 3 No. 2 Desember 2020, 70-84

\section{DAFTAR PUSTAKA}

Anonim. 2010. Pedoman Penyusunan Skripsi Sekolah Tinggi Ilnu Ekonomi Rahmaniyah sekayu. STIER

Arikunto, Suharsimi. 2007.Prosedur Penelitian Suatu Pendekatan Praktik. Cetakan Ketiga Belas. Jakarta: PT. Rineka Cipta

Dwi Laswiyati.(2005) Analisis Pengaruh Kompensasi, Tingkat Pendidikan Dan Lingkungan Kerja Terhadap Kinerja Pegawai Dinas Pengelolahan Keuangan Daerah Kota Semarang

Gunawan Didik. (2012) Pengaruh Disiplin Kerja Terhadap Produktivitas KinerjaPegawai Pada Kantor Bagian Umum Dan Pengadaan Setda Kabupaten Musi Banyuasin. Sekayu. STIER

Handoko. 2012. Manajemen Sumber Daya Manusia. Jakarta: PT. Bumi Aksara.

Hasibuan, Malayu S.P. 2012. Manajemen Sumber Daya Manusia. Edisi Jakarta: Kencana Pranada Media Grup

Keputusan Menteri Nomor 158 Tahun 2014 Tentang Pedoman Organisasi Kecamatan

Kurniawan.(2005) Analisis Pengaruh Motivasi Dan Disiplin Kerja Terhadap Kinerja Pegawai Badan Pemberdayaan Masyarakat Dan Desa Kabupaten Lahat

Noor, Juliansyah. (2011) Metode Penelitian : Skripsi, Tesis, Disertasi Dan Karya Ilmiah. Jakarta: Kencana

Sanusi. 2013. Manajemen Sumber Daya Manusia. Jakarta: PT. Bumi Aksara. Simmamora. 2011. Manajemen Sumber Daya Manusia. Edisi Revisi.Cetakan Keenam Belas. Jakarta: PT. Bumi Aksara.

Sugiono.2009. Statistik Untuk Penelitian . Bandung: Alfabeta

Sugiyono.2014. Metode Penelitian (pendekatan kuantatif,kualitatif dan $R \& D$ ) . Bandung: CV.Alfabeta

Supangat.(2008) Coorporate Learning, Yogyakarta: Pustaka Belajar Sutrisno, Edi. 2010. Manajemen Sumber Daya Manusia. Edisi Pertama. UU Nomor. 22 Tahun 1999 Tentang Pemerintah Daerah.

Widianto, (2010) metode penelitian tindakan kelas, Bandung, PT. Remaja Rosdakarya

Widiyanto. 2010. Metode penelitian pendekatan praktis Jakarta: PT. Bumi Aksara.

Zainal, Veithzal Rivai, dkk. 2014 Manajemen Sumber Daya Manusia Untuk Perusahaan. Edisi Ke 3. Jakarta : Rajawali Pers. 